\title{
Ultra-high-resolution marine 2D-3D seismic investigation of the Liman Tepe/Karantina Island archaeological site (Urla/Turkey)
}

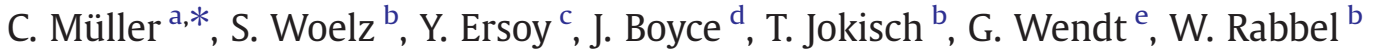 \\ a Inst. of Geosciences, Dep. of Geophysics, Kiel University, Otto-Hahn-Platz 1, D-24118 Kiel, Germany

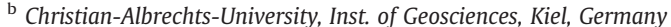 \\ c Bilkent University, Dept. of Archaeology and History of Art, Bilkent, Ankara TR-06800, Turkey \\ d McMaster University, School of Geography and Earth Sciences, Hamilton, Ontario, Canada \\ e Rostock University, Inst. of Communications Engineering, Rostock, Germany
}

\section{A R T I C L E I N F O}

\section{Article history:}

Received 6 November 2007

Accepted 31 October 2008

\section{Keywords:}

Ultra high resolution

3D seismic acquisition

Clazomenae

Ionia

Western Turkey

Archaeology

SEAMAP-3D

\begin{abstract}
A B S T R A C T
2D and 3D high-resolution seismic investigations were performed on submerged coastal archaeological sites at Iskele and near to Karantina Island in the Bay of Izmir in western Turkey. Tectonic subsidence of the coastline has submerged a number of archaeological features associated with an important Early Bronze Archaic settlement (Liman Tepe) and the classical Ionian city of Clazomenae. Seismic surveys were focused on imaging of an Archaic harbour structure and other submerged Hellenistic and Roman architectural features. Seismic data were acquired with the SEAMAP-3D ultra-high-resolution 3D marine seismic acquisition system developed for detailed archaeological site investigation.

A 2D reconnaissance survey was performed over a $2 \mathrm{~km}^{2}$ area around Karantina Island to evaluate the seismic penetrability and to locate sites for further 3D investigation. This survey predominantly revealed marine sediment layers covering the local bedrock, which is characterized by scattering of seismic energy showing its rocky nature.

Two ultra-high-resolution 3D seismic surveys were performed. The first covered a $350 \mathrm{~m} \times 30 \mathrm{~m}$ area in the modern harbour targeting a prominent Archaic harbour structure. The second was acquired across a $120 \mathrm{~m} \times 40 \mathrm{~m}$ area on the southeast shore of the Karantina Island close to a Roman architectural feature. The 3D surveys were acquired with nominal line spacings of $1 \mathrm{~m}$, using a $8 \times 4$ pseudo-rigid hydrophone array and a Boomer source firing at $3 \mathrm{~Hz}$ shot frequency. Automated processing of the seismic data using a portable Linux cluster provided stacked 3D seismic volumes with $25 \mathrm{~cm} \times 25 \mathrm{~cm}$ bin size on-site.

The 3D seismic survey of the harbour clearly imaged the submerged Archaic structure and the underlying sediment sequence. The seismic time slices reveal two seismic anomalies (2-3 $\mathrm{m}$ in diameter) in the harbour basin sediments. The 3D surveys southeast of Karantina identified a thicker marine sediment sequence overlying steeply dipping bedrock reflectors. The sediment sequence records the rapid accumulation and progradation of the coastline following the construction the Alexander causeway linking the mainland with the island in 334 B.C.
\end{abstract}

(c) 2008 Elsevier B.V. All rights reserved.

\section{Introduction}

3D seismic acquisition has been employed for more than 20 years in the hydrocarbon industry but has had limited application in nearsurface archaeological and engineering surveys.

In archaeological work, the objective is commonly to locate buried architectural structures and small-scale man-made features at shallow depths of penetration (typically $<5 \mathrm{~m}$ ). Object detection at such shallow depths requires ultra-high-resolution seismic acquisition and processing methods. These include the use of high frequency,

\footnotetext{
* Corresponding author.

E-mail address: cmu@geophysik.uni-kiel.de (C. Müller).

URL: http://www.geophysik.uni-kiel.de/ cmu (C. Müller).
}

broadband seismic sources and processing routines that are geared to maximizing seismic resolution. These requirements and the need for specialised seismic processing hardware have largely limited the application of 3D seismic methods for many near-surface applications.

The recent advent of more powerful personal computers and PCbased seismic processing and interpretation software has made ultrahigh-resolution 3D seismic surveys feasible for marine archaeological work. Whilst the resolution requirements of archaeological and engineering surveys are significantly greater when compared to hydrocarbon exploration, at the same time the survey areas are much smaller, and thus the amount of data collected remains comparable to that typical in industry (i.e. tens or even hundreds of giga bytes). The advances in computer technology have thus stimulated the development and adaptation of 3D seismic acquisition in shallow geophysical 


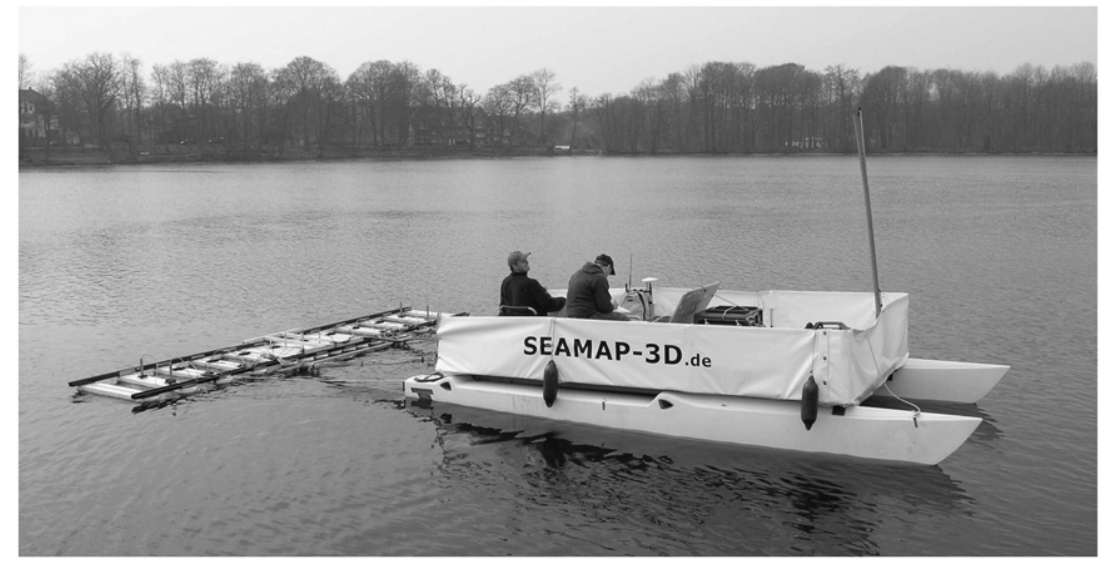

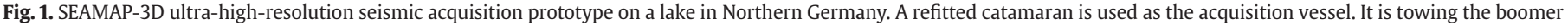
seismic source and the rigid frame hydrophone array.

studies. It is now possible to employ 3D seismic imaging for object detection and mapping of archaeological structures below the sea floor in full three dimensions.

In the last 15 years there has been growing interest in adapting high frequency seismic sources and 3D methods for marine seismic acquisition on a dense survey grid (Henriet et al., 1992). In 1998, within the context of the European MAST III project, efforts were taken for the first time to develop a high-resolution 3D marine seismic acquisition system (Marsset et al., 1998).

Other researchers have demonstrated that high- to ultra-highresolution 3D seismic acquisition is feasible in shallow water
(Missiaen et al., 2002; Müller et al., 2002; Müller, 2005; Pulliam et al., 1996; Scheidhauer et al., 2005) and that 3D methods can be downscaled to meet the horizontal and vertical resolutions needed for engineering applications. It is only relatively recently, however, that systems have been developed with a resolution suitable for application in archaeology (Bull et al., 2005; Vardy et al., 2008; Gutowski, 2005). Between 2004 and 2006 an ultra-high-resolution marine 3D seismic acquisition system was also developed at the ChristianAlbrechts-University in Kiel for detailed archaeological site investigation in very shallow water (Fig. 1). The project received the acronym SEAMAP-3D, which stands for SEismo Acoustical Marine

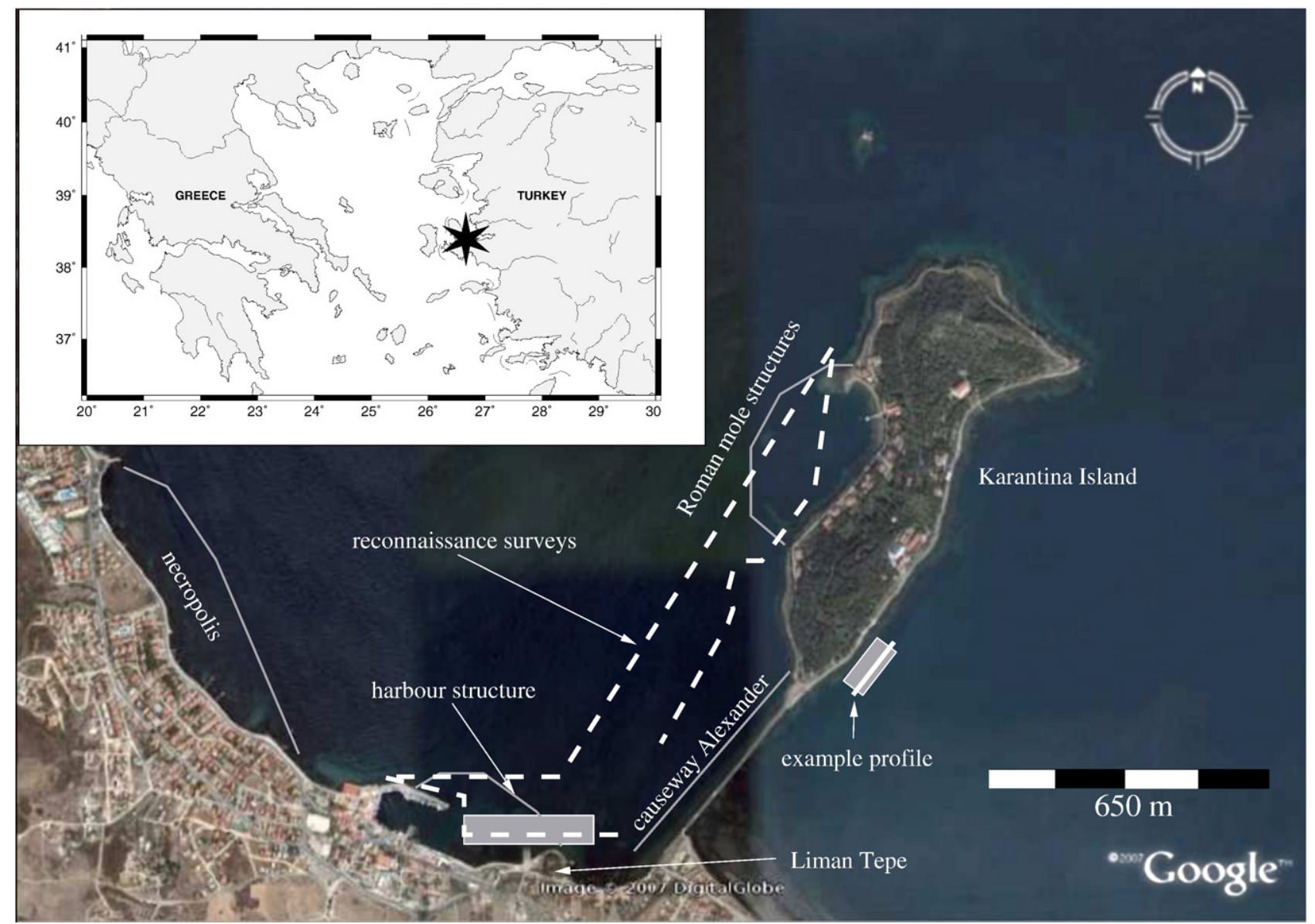

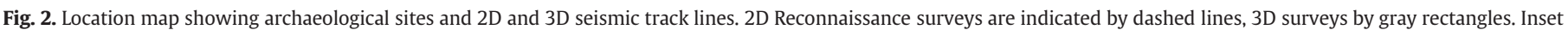
map showing location of study area and bay of Izmir in western Turkey. 
Archaeological Prospection in 3D. It is funded by the German Ministry of Education and Research (BMBF).

In this paper we report on the results of SEAMAP-3D seismic surveys performed on marine archaeological sites near Iskele and Karantina Island in western Turkey (Fig. 2). The area includes an important Bronze Age coastal settlement (Liman Tepe) and the architectural remains of the classical-Byzantine-age Ionian port city of Clazomenae. Ultra-high-resolution 3D seismic surveys were performed in 2006 with the objective of imaging submerged harbour structures and buried architectural features in shallow coastal waters surrounding these sites. The survey results demonstrate that ultra- high-resolution can be achieved in water depths of less than $2 \mathrm{~m}$. The paper also provides technical details of the SEAMAP-3D acquisition system and demonstrates how automated processing can be used to produce a stacked seismic data volume on-site, a few hours after the survey.

\section{Geologic and archaeological setting}

The study area is located on the south shore of the Bay of Izmir, about $10 \mathrm{~km}$ north of the city of Urla, Turkey (Fig. 2). The Bay of Izmir lies over a major fault-bounded basin (Izmir Graben) formed by

Unit A, Massive brownish-grey fine sand

Unit B, Dark grey Poseidonia -rich sandy silt

Unit C, Light grey laminated clay and silt

Unit D, Brownish-grey matrix to clast-

supported sandy gravel with shell fragments

Unit E, Greyish-brown pebble and shell hash

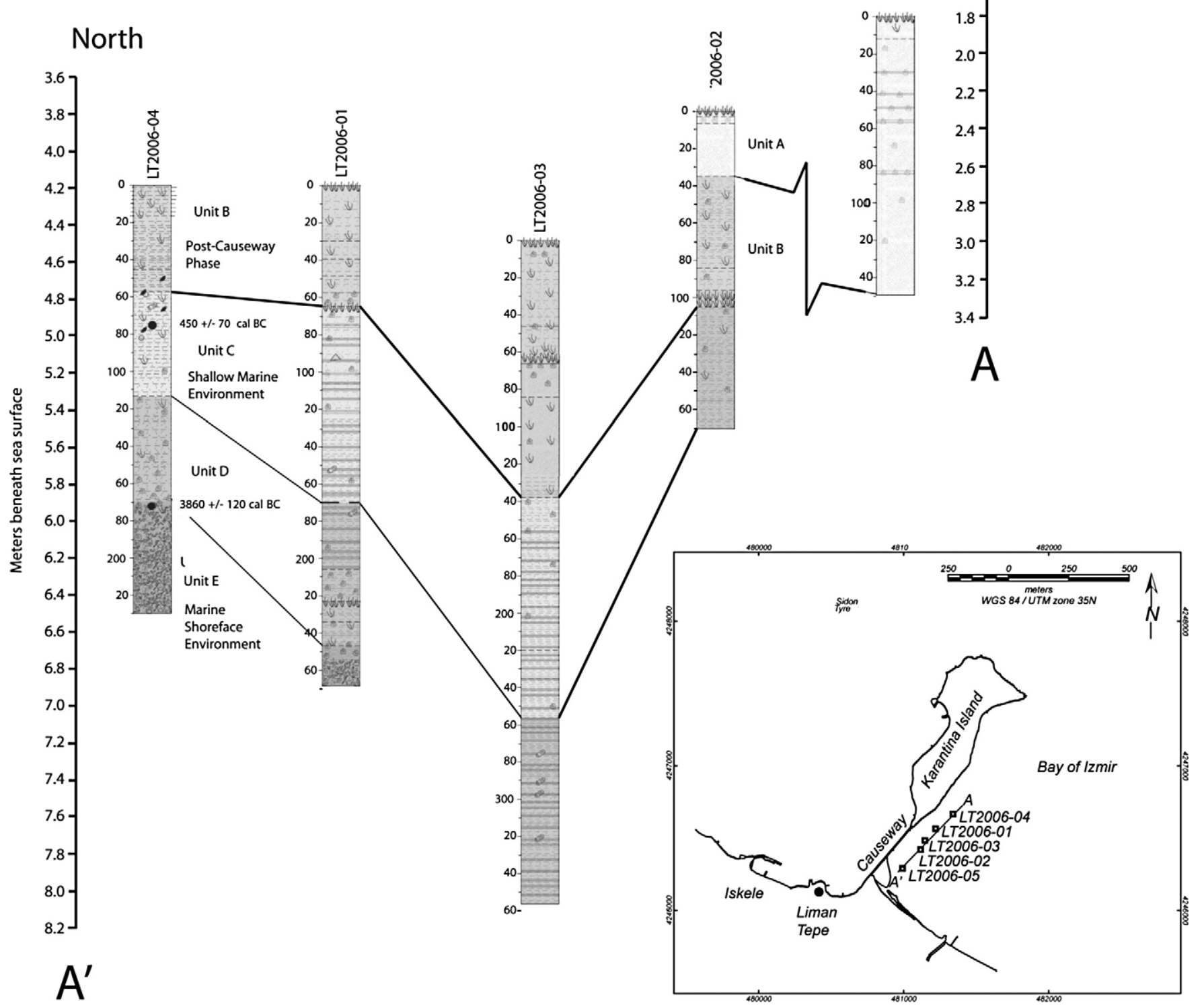

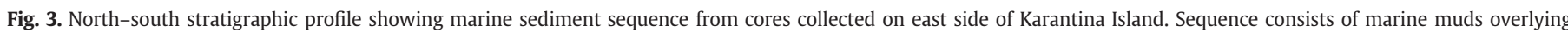
lagoonal and foreshore deposits (Krezoski et al., 2007). 
Oligocene-Miocene extensional faulting (Bozkurt and Sobilir, 2004; Brinkmann, 1970). The coastline is subject to active seismicity and coseismic tectonic subsidence. The basement rocks below the area consist of Cretaceous schists and overlying Neogene sedimentary strata and volcanics. Within the study area the local bedrock consists of Neogene carbonates, which are draped by thin Pleistocene and Holocene marine sediments (Aksu et al., 1987). The Holocene sediments consist of muds, silts overlying older marine sands and terrestrial sediments deposited during lowered phases of sea level (Fig. 3) (Goodman et al., 2007; Krezoski et al., 2007). The marine sediment thickness is greater on the eastern side of Karantina Island owing to its more sheltered location behind the Alexander causeway (Fig. 2). The causeway construction in ca. 334 BC blocked the natural west to east longshore transport of sediment along the coast, creating a sheltered embayment with more rapid sediment accumulation to the east of the island. The sediment accumulation on the western side of Karantina Island has been much less extensive, as indicated by the presence of bedrock outcrops and relict wadi and shoreline features on the modern seabed. The relict shoreline features record early Holocene lowstand phases when sea levels were more than $10 \mathrm{~m}$ below present (Krezoski et al., 2007).

The area is of great archaeological importance, as it contains a number of long-occupied coastal archaeological sites that were inhabited from the prehistoric times to Byzantine era. The small coastal promontory to the east of the modern harbour of Iskele (Liman Tepe; Fig. 2) was the site of an important prehistoric (Chalcolithic Bronze Age) coastal settlement (Sahoglu, 2005). Later in the Archaic and Classical period Iskele and Karantina Island were host to the much more extensive Ionian port city of Clazomenae.

Excavations at Clazomenae have yielded substantial material evidence of the 7th and 6th centuries BC and reveal a pattern typical for the cities established by the Ionians migrating from various regions in mainland Greece in the early first millennium BC.

The main area of occupation of the Ionic settlement was confined to the surrounding of the prehistoric mound. In the course of time, triggered by an increase in population, it extended further to the south and to the west of the prehistoric site. The heyday of Clazomenae, like other city-states in the Eastern Aegean, was definitely the Archaic period, 7th and 6th centuries BC (Ersoy, 2004a,b). There are two landmark events concerning Clazomenae. The attacks by the Persian troops on the coastal cities of Asia Minor that took place in $546 \mathrm{BC}$ and in 499/4 BC respectively, dramatically affected population movement in the region. For Clazomenae this resulted in the abandonment of the Archaic settlement on the mainland, and the establishment of the new urban center on the off-shore Karantina Island. Because of the dense vegetation, ancient remains are hardly visible on today's Karantina Island. There was a Greek type theater on the northern tip of the island and Athena temple on top of flat terrain of the north hill. Earlier excavations by Giorgos Oikonomos on the island revealed part of a paved road on its west coast as well as remnants of spacious villas on its east shore. Large segments of these living units are now submerged and their remains are partly visible under the sea. This aspect makes these remains an ideal target for seismic investigation. One of the most important discoveries recently made at Clazomenae involves the study of underwater remains offshore of the prehistoric mound (Artzy, 2001). The thick formation under the sea, also visible on the aerial photographs, was thought to be part of the harbour facility associated with the prehistoric citadel. The nature of the architectural remains and numerous small finds, dating from the seventh through the end of the sixth centuries, collected in this underwater research seriously challenged this idea and suggest that this thick structure was quite likely part of the archaic fortification wall defending the settlement from the north. It is obvious that part of the Archaic settlement had sunk into the sea after severe tectonic changes. This must have been caused by the abrupt deformation in the coastline, following a significant seismic event. Approximately $2 \mathrm{~km}$ to the northwest of the ancient settlement on the mainland, immediately next to the modern coastline was part of the cemetery that produced numerous graves in rectangular compounds (Hürmüzlü, 2004). Parts of walls extending further to the northeast of the cemetery are now under the sea; and these remains suggest that originally the burial ground in the area was much larger and buried under the sea because of the tectonic change that very likely took place in the late Archaic period.

\section{The SEAMAP-3D seismic acquisition system}

The SEAMAP-3D system consists of an offshore acquisition and an onshore processing and imaging component. For acquisition we have refitted an old sailing catamaran, which is hosting a small generator, the power supply for the boomer seismic source, a real time kinematic differential GPS with a source mounted antenna, a 24-bit, 32 channel recording unit as well as an online navigational display. Fig. 4a shows a diagram of the technical setup on board the catamaran. The boomer is an electromechanical seismic source emitting acoustic frequencies a)

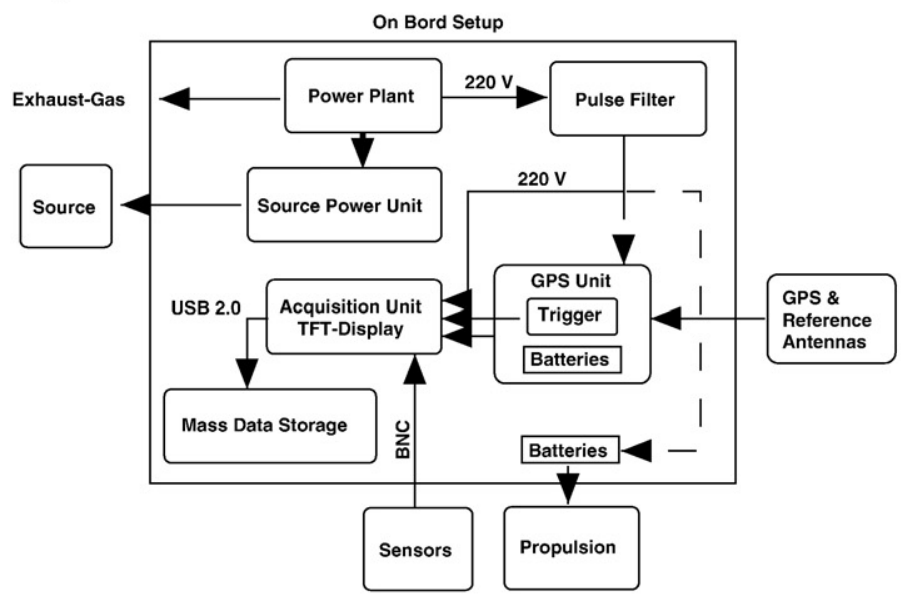

b)

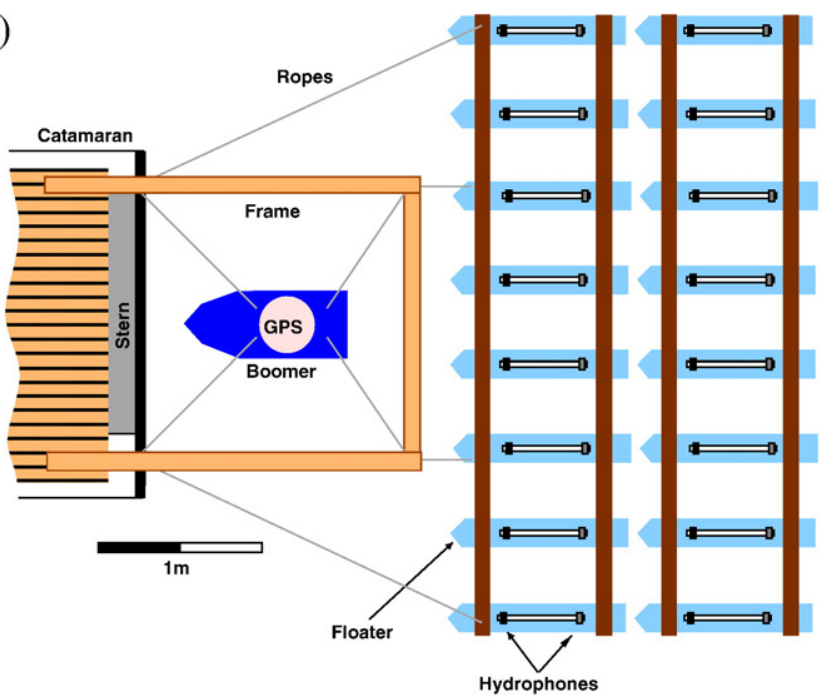

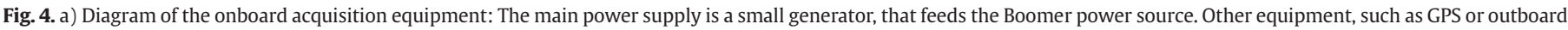

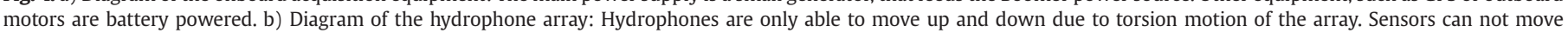
horizontally relative to each other. 

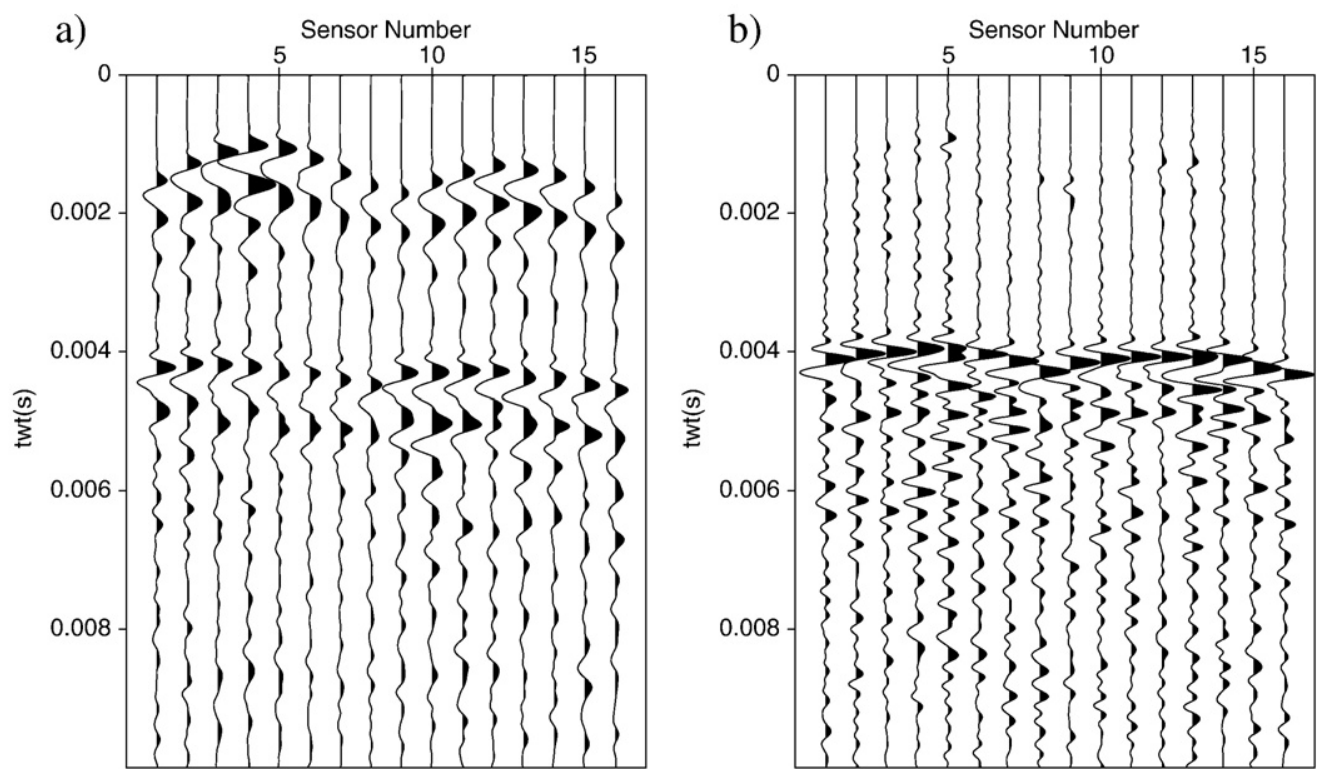

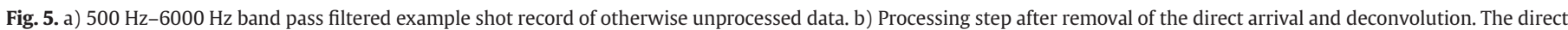
arrival is removed and deconvolution is applied on a channel by channel basis.

between $100 \mathrm{~Hz}$ and $6000 \mathrm{~Hz}$. It generates a sharp, well repeatable signal. The vertical resolution in water or water saturated sediments is of the order of one decimeter.

Fig. $4 \mathrm{~b}$ shows a diagram of the sensor array layout. During the survey the catamaran was towing two hydrophone arrays with 16 hydrophones each. The sensors were separated by $0.5 \mathrm{~m}$ and formed an evenly spaced $8 \times 4$ sensor array. Two hydrophones are attached to each flotation device within the array. Eight floats were arranged in parallel and connected by rigid beams that allow only limited torsion around the horizontal axis perpendicular to the vessel travel direction. Thus the hydrophones can only move vertically with wave motion and not horizontally relative to each other. The relative vertical motion of the sensors is typically of the same magnitude as the wave height (peak to peak).

The software for acquiring the seismic data and the online display of navigation data were written in Labview at Kiel University. The position of the source is directly recorded to the headers of seismic Unix formatted SEGY data files. At the same time the orientation of the vessel, and also the orientation of the rigidly attached sensor array, are measured by a digital compass. This heading information is also logged to the seismic headers for each shot fired. Later, in the processing phase of the survey, this information and the knowledge of the array geometry, combined with the relative position between source and receivers, are used to calculate the overall geographical position of the sensors and the source. Given a nominal source position precision of $2-5 \mathrm{~cm}$ from the real time kinematic GPS system and a heading precision of better than $1^{\circ}$, we can estimate the overall horizontal positioning precision of the sensors at a distance of $2 \mathrm{~m}$ from the source as $10-20 \mathrm{~cm}$.

We were using a shot rate of $3 \mathrm{~Hz}$, a sampling rate of $100 \mathrm{kHz}$ and a total recording time of $30 \mathrm{~ms}$. Using these settings data are recorded at a rate of $11 \mathrm{Mb} / \mathrm{s}$. The vessel's speed over ground ranges between $10 \mathrm{~cm} / \mathrm{s}$ and $20 \mathrm{~cm} / \mathrm{s}$, resulting in a shot separation between $3 \mathrm{~cm}$ and $7 \mathrm{~cm}$. Fig. 5a shows a $500 \mathrm{~Hz}-6000 \mathrm{~Hz}$ band pass filtered example shot record of otherwise unprocessed data (only 16 channels are displayed).

The vessel is steered by hand. It has two electrical outboard motors and the operator has to keep the ship as close to the track as possible. Nominal track separation was $1 \mathrm{~m}$. Despite the complexity of the acquisition system and the comparably difficult acquisition procedure, a routine seismic exploration of a soccer field sized area is possible in approximately half a day. Some of the biggest challenges the system faces are weather constraints and sea state. Wave motion does not only hamper necessary steering precision, but also adversely influences data quality. This is mostly due to increased irregular statics and swell noise. Even though the catamaran can be operated in up to $5 \mathrm{Bft}$ weather, 3D seismic acquisition has a limit of $3 \mathrm{Bft}$.

The onshore part of the system consists of a portable Linux cluster with 8 CPU's and $0.5 \mathrm{~Tb}$ of RAID disc space. Data processing is done by a pre-defined processing sequence that comprises of geometry setup, filtering, removal of direct arrival, spiking deconvolution, wave motion correction based on automatic threshold driven seabed picking, binning and stack or optional constant velocity prestack migration. Using this strategy, a seismic cube and time slice sequence can be provided on-site by over-night automated processing. Subsequent seismic interpretation is done manually.

Fig. 6 shows four stages of the processing sequence, in order to illustrate achievable improvements in data quality. The profile is a common offset gather from the survey performed at Karantina Island. The data shown are recorded with one hydrophone from the array at a source receiver offset of $1.15 \mathrm{~m} \pm 0.1 \mathrm{~m}$. Fig. 6a displays the section after band pass filtering to remove low frequency bursts attributed to swell. The trapezoidal filter passed a frequency band between $800 \mathrm{~Hz}$ and $5000 \mathrm{~Hz}$ with cut-off frequencies at $500 \mathrm{~Hz}$ and $6000 \mathrm{~Hz}$ respectively. The section is dominated by reverberation in the direct arrival and in the reflected signal, but also illustrates the static jitter introduced by wave motion. The ringing observed in the data is either generated by the catamaran's hulls or within the rigid array itself. We postulate a noise model where seismic energy transmitted directly into the array (or the hulls) has different reverberation characteristics than energy reflecting from the subsurface. Reverberation in the direct arrival interfere with reflected energy making deconvolution less effective. We assume that the ringing in the direct arrival is additive to the reflected energy and can simply be subtracted given an appropriate operator. Reverberation in reflected energy are later removed by deconvolution. Thus the first step taken to improve the situation is to remove the direct arrival. We assume that the subsurface changes from shot to shot and construct an operator to remove the direct arrival by simply calculating a stacked trace average for each receiver. The operator is subsequently subtracted from each trace and thus the reverberating direct arrival removed. Fig. 6b shows the section after removal of the direct wave. Even though the process effectively removes the direct wave, it will always introduce horizontal artefacts. In order to remove the reverberation from reflected energy we calculate an average autocorrelation function for each channel and 

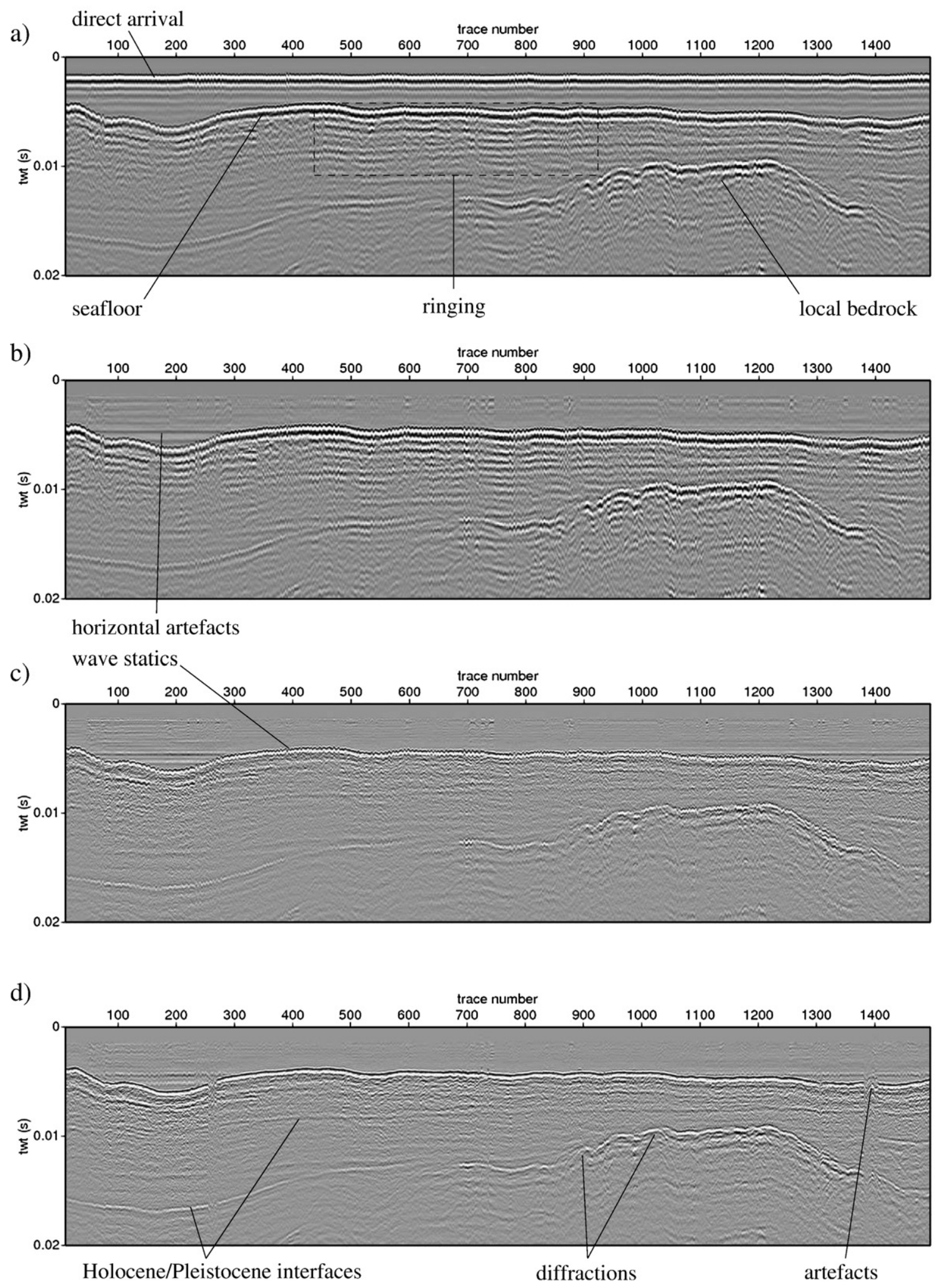

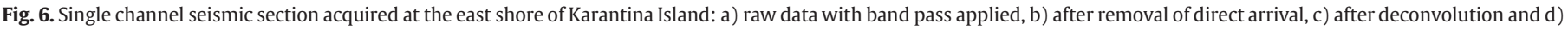
after nmo, tide and residual statics correction. Further details in text.

postulate that the autocorrelation represents the reverberation alone. The desired source signal is not extracted from the data itself but synthetically generated, assuming that the Boomer signal can be represented by half a Ricker wavelet of suitable frequency content. The deconvolution operator is then derived as a Wiener shaping filter and applied to the data (Fig. 6c). The final section shows the data after removing irregular residual static shifts and tidal statics. Fig. 5b shows a single shot record after removal of direct arrival and reverberation energy. Tidal effects are removed by using the height information derived from GPS data. We assume that the water level does not significantly change while acquiring one single profile. Thus the average of the antenna height is used to shift seismic data to a reference datum. 
Wardell et al. (2002) presented an approach based on common offset spatial averaging (COSA) to remove positional variations from high frequency 3D seismic data. It would be the preferable method, but since one of SEAMAP-3D project aims is to provide automated processing, we reverted to a simple two dimensional two stage heuristic method, which, however gives acceptable results for our purpose. In the first stage travel times to the seabed are evaluated by an autopicker, which is based on a simple amplitude threshold criterion. Since the amplitude value that is actually picked is located somewhere on the slope between onset of the event and the first amplitude maximum, a crosscorrelation between adjacent traces is calculated in a window around the picked travel time. By doing so, we can determine the actual shift between

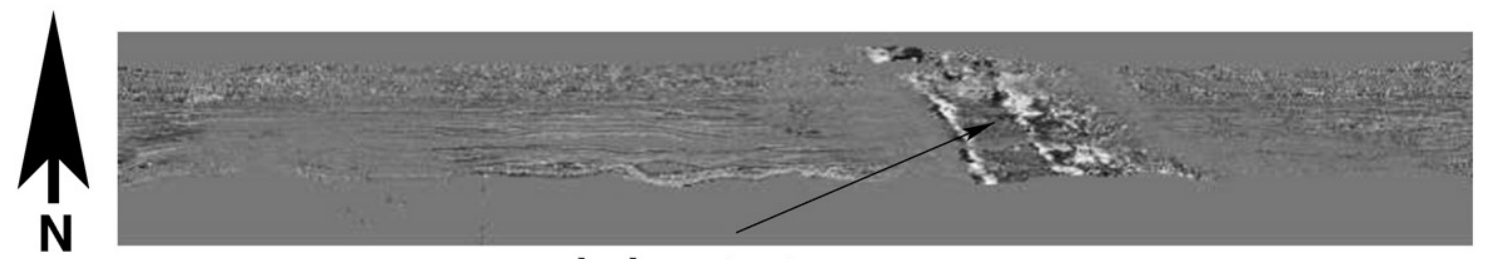

$1.3 \mathrm{~m}$

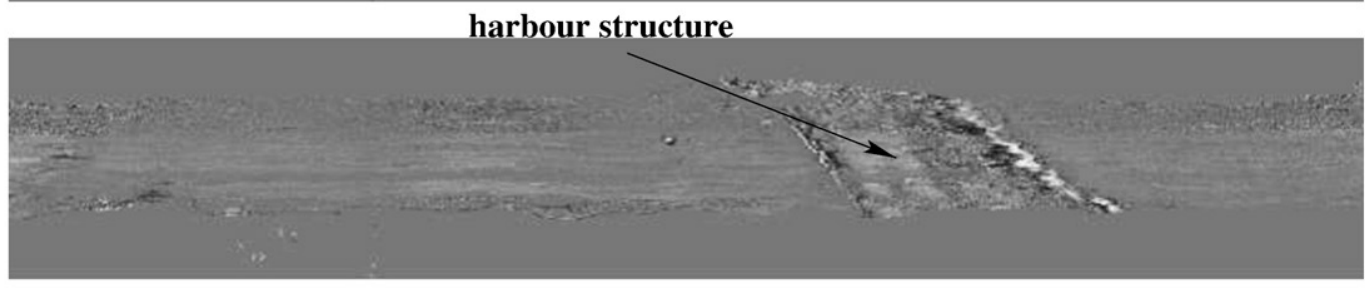

$1.73 \mathrm{~m}$

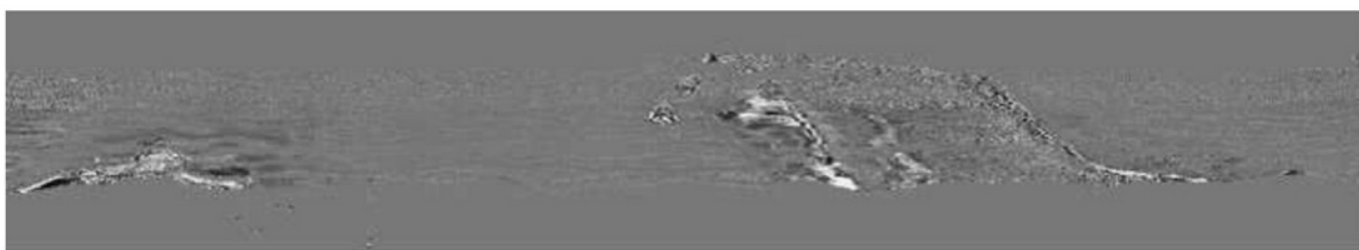

$2.16 \mathrm{~m}$

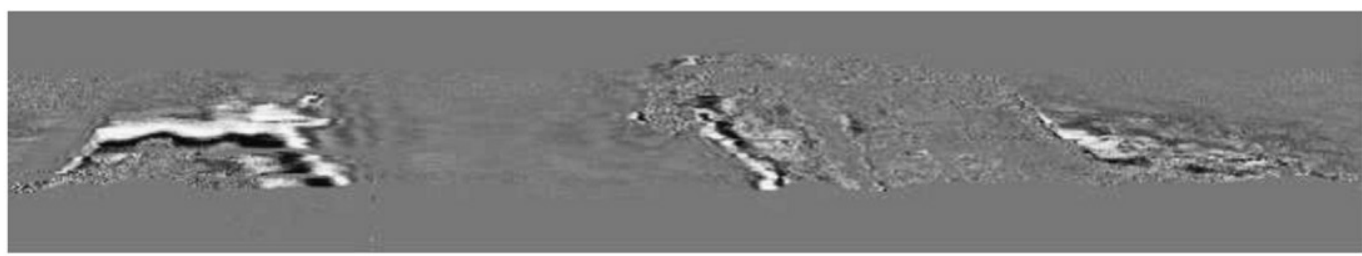

$2.6 \mathrm{~m}$

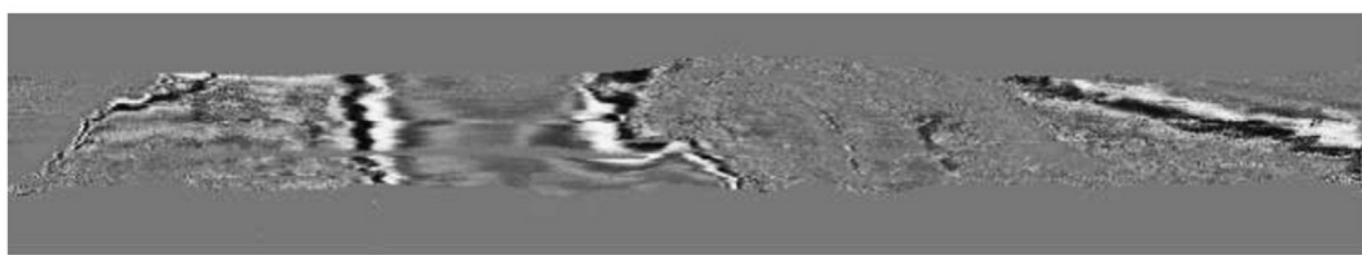

$3.0 \mathrm{~m}$

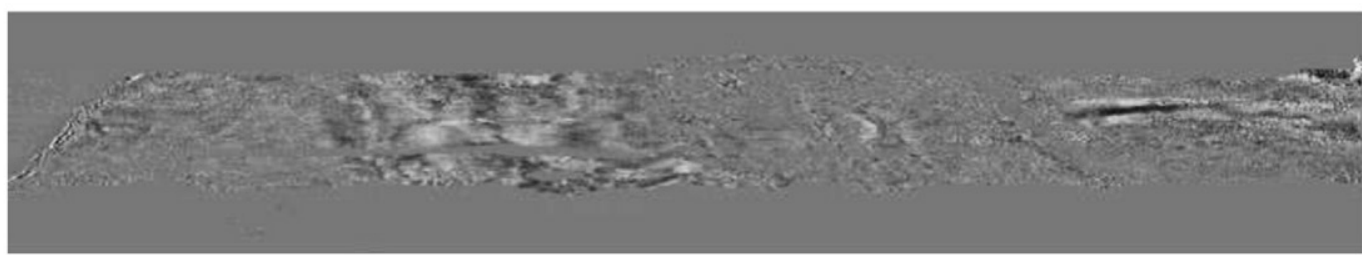

$3.6 \mathrm{~m}$

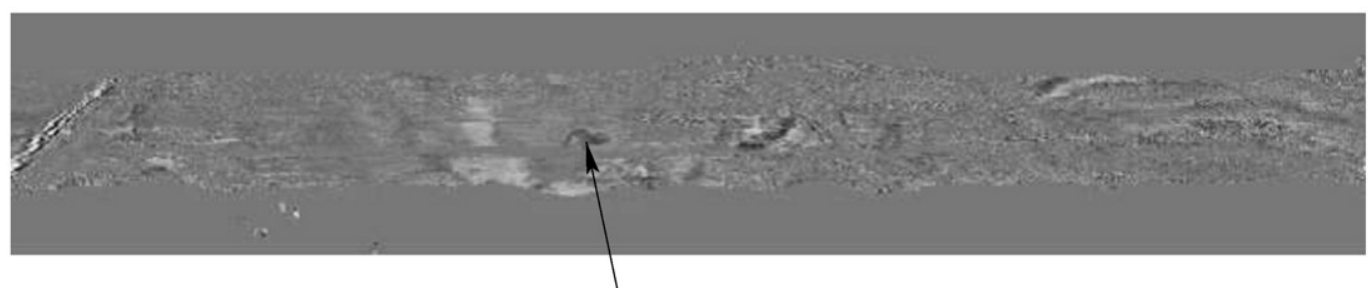

$4.2 \mathrm{~m}$

Fig. 7. Sequence of time slices through the unmigrated 3D seismic data cube acquired at the location of the harbour structure at Liman Tepe. Depth conversion assuming constant seismic velocities of $1500 \mathrm{~m} / \mathrm{s}$. Further description in text. 
neighbouring traces. Presuming that the statics introduced by wave motion has a higher spatial frequency than the seafloor topography, in the second stage we run a median followed by a moving average filter over the travel time data. The residual statics to be applied, are the

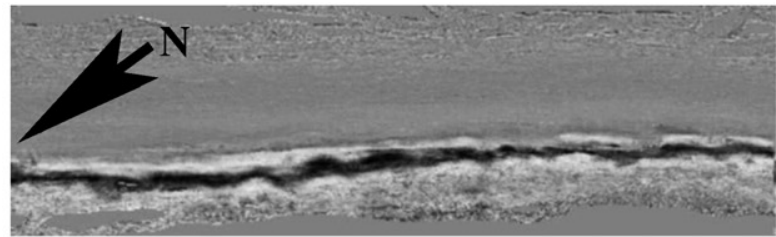

$2.25 \mathrm{~m}$

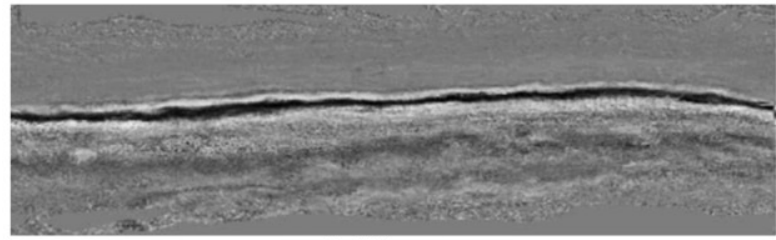

$3.00 \mathrm{~m}$

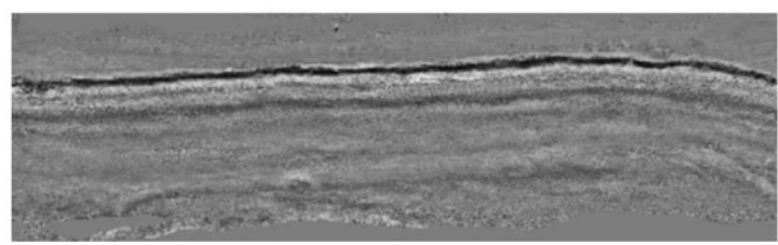

$3.75 \mathrm{~m}$

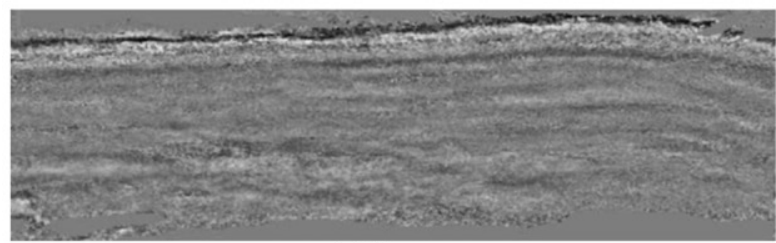

$4.50 \mathrm{~m}$

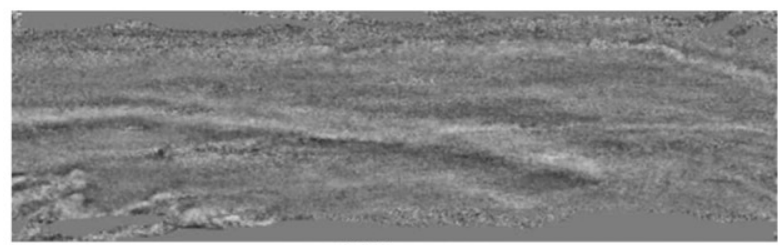

$5.25 \mathrm{~m}$

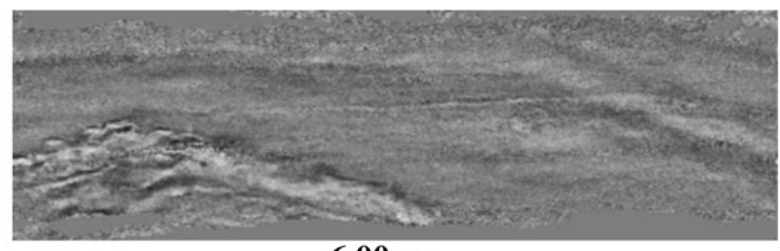

$6.00 \mathrm{~m}$

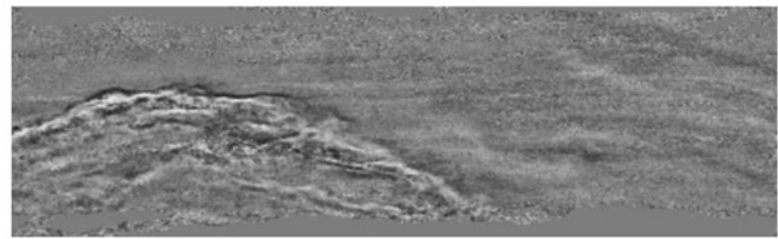

$6.75 \mathrm{~m}$ difference between the filter output and travel times determined in the first stage (Fig. 6d). Although the approach is heuristic, the validity of the assumptions made can be evaluated by the lateral coherence of seismic data in the binned seismic data volume. Since we can assume sediments

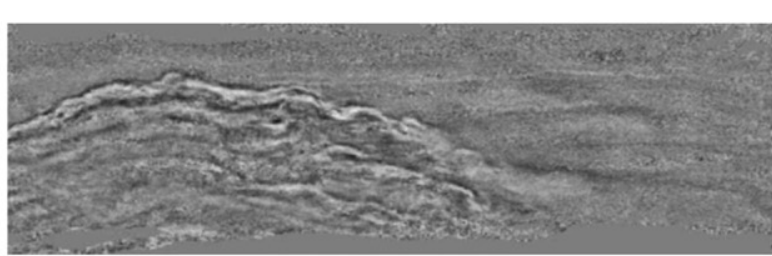

$7.50 \mathrm{~m}$

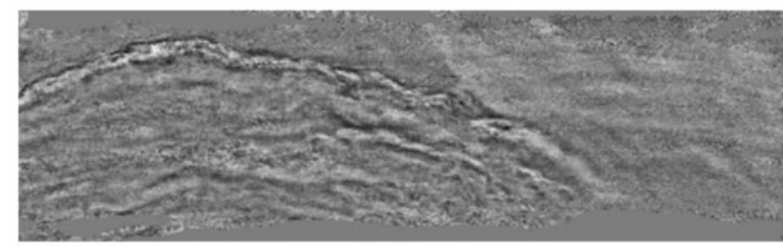

$8.25 \mathrm{~m}$

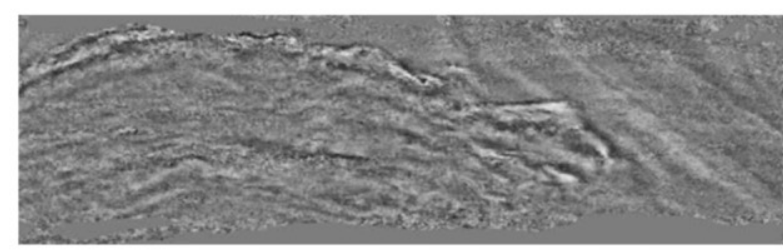

$9.00 \mathrm{~m}$

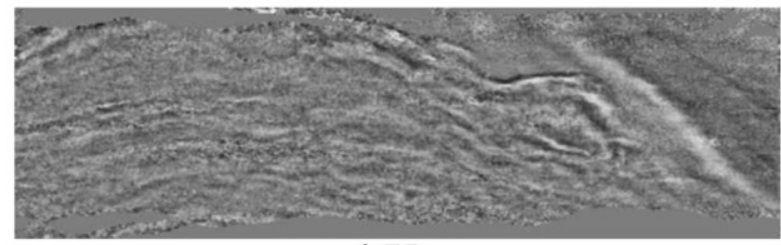

$9.75 \mathrm{~m}$

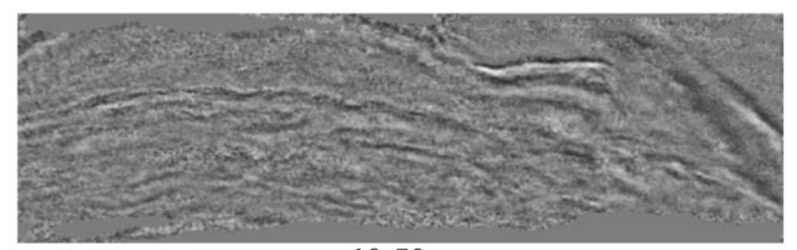

$10.50 \mathrm{~m}$

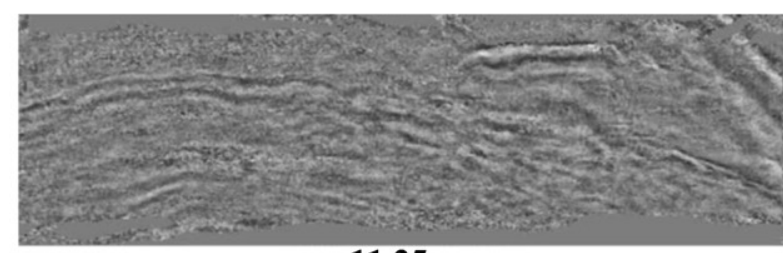

$11.25 \mathrm{~m}$

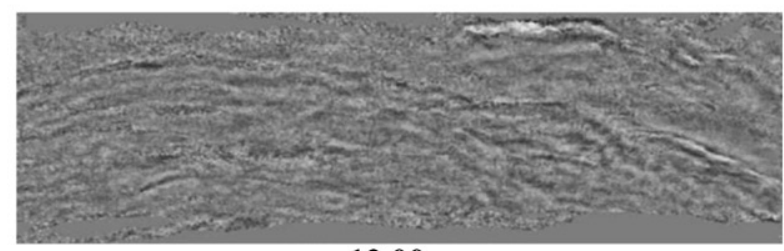

$12.00 \mathrm{~m}$

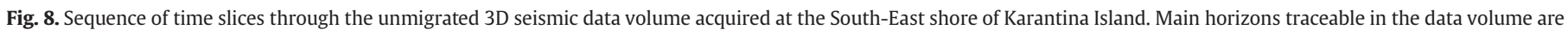
the seabed (inundated shore line, $2.25 \mathrm{~m}-3.75 \mathrm{~m}$ ), Holocene and Pleistocene sediment interfaces (3.00 m-7.50 m) and the local bedrock (5.25 m-10.50 m). 

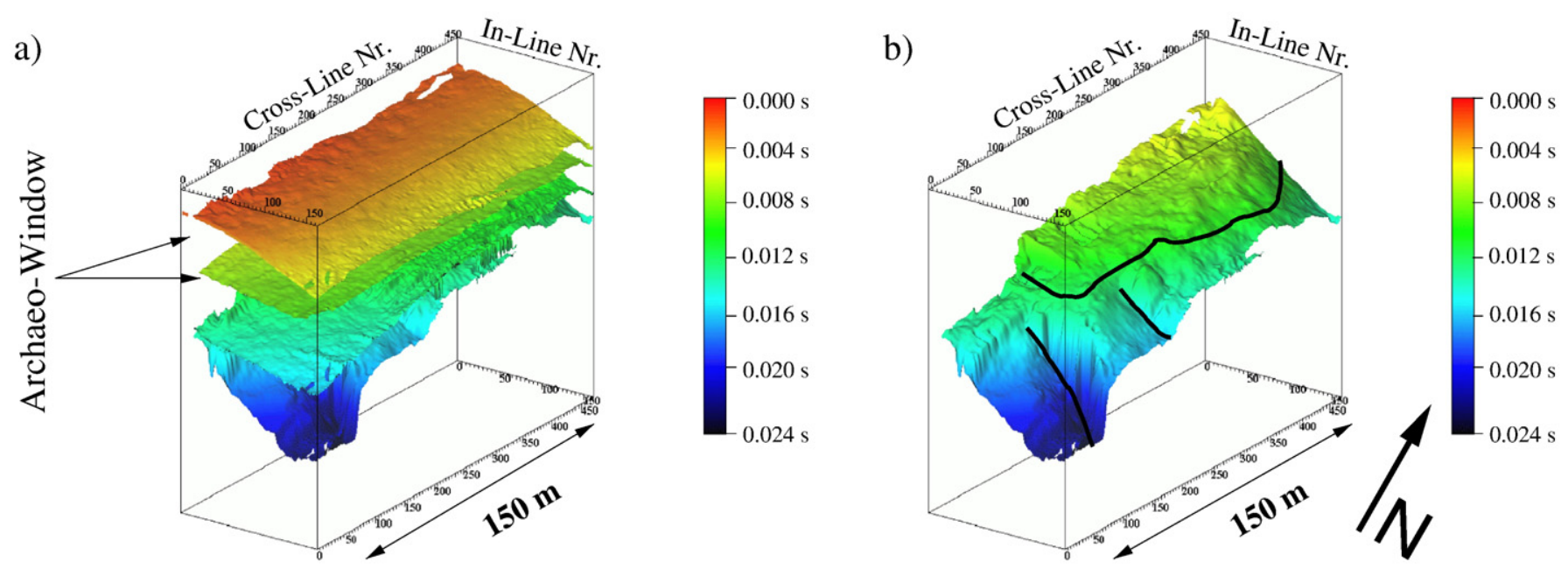

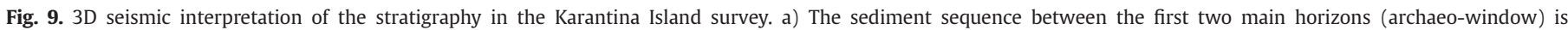

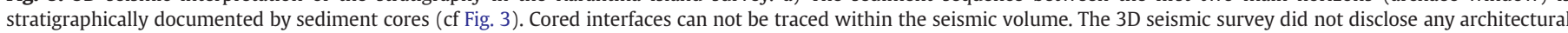
features within this depth range. b) local bedrock horizon exhibiting two sharp drop-offs related to tectonic activity in the area.

to be water saturated and having seismic velocities close to that of water, binning or migration is done with a constant velocity of $1500 \mathrm{~m} / \mathrm{s}$ in the final processing step. The bin size of the final data volumes was $25 \times 25 \mathrm{~cm}$. All processing as demonstrated here was done with Seismic Unix (Stockwell, 1999). Processing modules developed in the project are based on Seismic Unix. Time intensive modules where parallelised whenever possible using the Message Passing Interface library LAM/MPI (Burns et al., 1994; Squyres and Lumsdaine, 2003). Please note that the assumptions involved with the residual statics correction and the assumption of a homogeneous velocity field are only approximations. They are accepted in favour of processing speed over processing precision, since another of the objectives of SEAMAP-3D is to provide a 3D seismic volume on-site. More sophisticated corrections, such as COSA, or seismic velocity analysis can still take place if desired in a later stage since all necessary information to do so is available.

\section{Reconnaissance surveys}

A number of $2 \mathrm{D}$ reconnaissance surveys were performed to evaluate seismic penetrability of the sediments and to pinpoint locations of interest for further investigation with an ultra-highresolution 3D survey. They covered parts of Liman Tepe and the modern harbour of Iskele as well as the western part of the Karantina Island shore (Fig. 2a). Overall, sediments show good seismic penetrability.

The 2D surveys were performed with the SEAMAP-3D acquisition system. However, only one hydrophone of the array was used. Acquisition parameters and the processing sequence are as described above.

The investigated area is mainly characterised by four seismic horizons. Below the seabed horizons are caused by the transition between Pleistocene to Holocene sediments. In some places local anomalies are observed as diffraction signatures or short reflector elements. The local bedrock constitutes the seismic basement in the area and is characterised by scattering and phase reversals of the seismic signal, showing its brittle nature. Phase inversion of seismic signal, as associated with the seismic basement, could be attributed to decay of organic material covering bedrock horizon (see Fig. 6).

The submerged structure in the harbour close to Liman Tepe is identified in the data by its seafloor topography, but is generally seismically impenetrable. The same observation holds for the Roman mole structures to the west of Karantina Island (see Fig. 2). Part of the seismic energy is scattered at the rough surface of these architectural features. Possibly, organic material covering the structures adds to the loss of usable seismic signal.

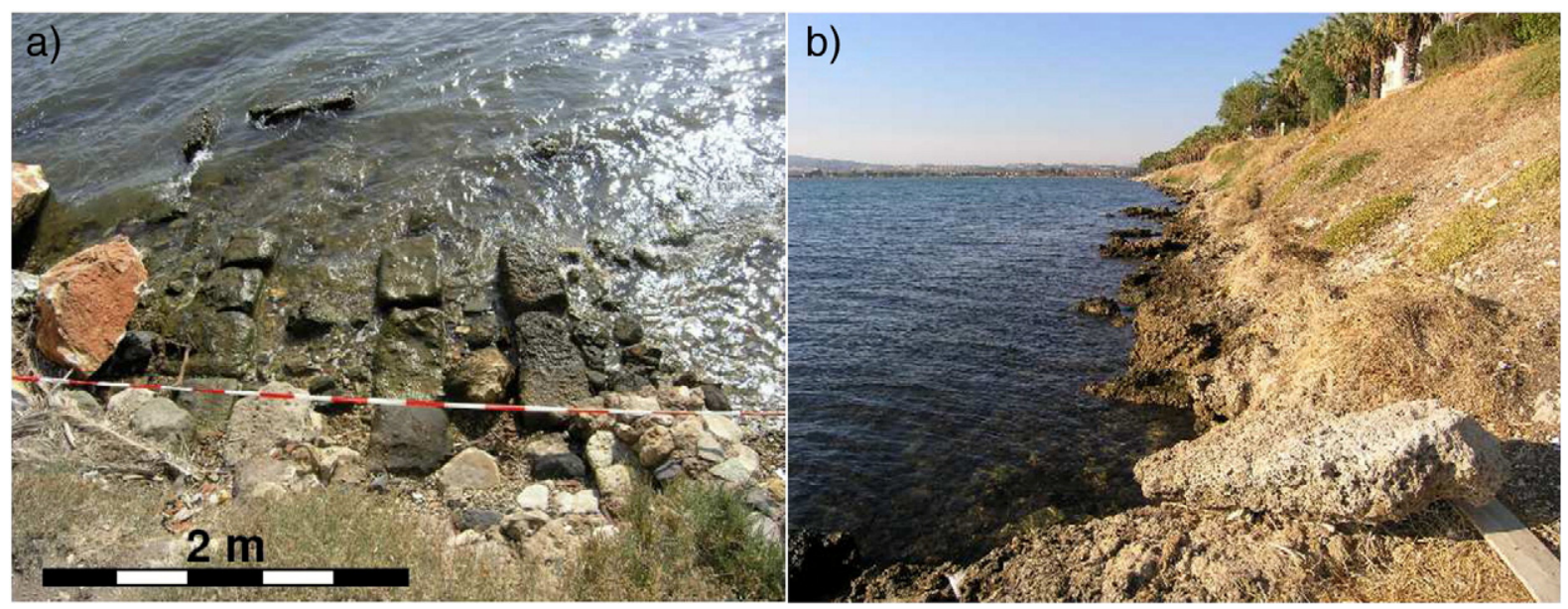

Fig. 10. Images of the shore area at Karantina Island: a) Roman villa foundation walls suggested further building remains in the water. b) Rough shore line of the island. 


\section{Ultra-high-resolution 3D surveys}

3D seismic investigation initially focused on the Liman Tepe offshore site and the submerged harbour structure. Even though seismic penetrability of this area, especially the structure itself, is not favourable, it was still chosen for a 3D survey due to its overall archaeological importance. The survey covers a $350 \mathrm{~m} \times 30 \mathrm{~m}$ area over the submerged breakwater wall structure west of Liman Tepe and close to the modern harbour. Due to weather constraints (winds up to $5 \mathrm{Bft}$ ) this survey had to be aborted and further work was only possible in the lee shore south-east of Karantina Island. This second survey spans a $120 \mathrm{~m} \times 40 \mathrm{~m}$ area close to the south eastern shore of the Karantina Island (see Fig. 2a, boxes). An area was chosen for investigation, where Roman villa foundation walls are still visible at the shore (see Fig. 10a). Both 3D surveys reveal highly detailed images of the seabed and sub-seabed structures.

The harbour survey clearly images the topography of the submerged structure in the harbour (see Fig. 7 for time slice sequence) and is in excellent agreement with a recent bathymetric survey carried out by McMaster University. Below the seabed we find weak reflections from sediment interfaces and the signature of a local anomaly with 2-3 m diameter.

The regional geological setting does not suggest the presence of large stones or boulders producing the diffraction signatures as observed in the 3D data. It is more likely that these are caused by man made structures, which thus might be of archaeological or historical relevance. The anomalies are not processing artefacts, as can be deduced from their lateral coherence in the timeslices. The anomalies are larger than the horizontal resolution and bin size of the 3D data set. However, only ground truthing can prove any archaeological relevance.

At the Karantina Island Roman Villa site we could not identify signatures of wall foundations in the 3D seismic data set. Due to hazardous boulders at the seafloor in immediate shore vicinity, the survey area was positioned about $20 \mathrm{~m}$ off the shore. It thus cannot be determined if any building remains exist in the section not covered by the seismic investigation.

However, the resulting 3D seismic data volume is of very good quality. It imaged the inundated shore line, the underlying sediment formation and local bedrock (see Fig. 8). Four main horizons were interpreted in the 3D data set, i.e. the seabed, two sediment interfaces and the local bedrock (Fig. 9a). Sediment cores, however, only cover up to approximately $4 \mathrm{~m}$ of the sediment column from the seabed (indicated as archaeo-window in Fig. 9a, also refer to Fig. 6) and thus do not penetrate the second seismic horizon. Unfortunately cored interfaces can not be traced clearly in the seismic data volume due to a lack of impedance contrast. They are however visible on individual seismic sections.

The sediment package between the seabed and second horizon is of archaeological interest, but does not reveal any structures of possible relevance. The third sediment interface skirts around an outcrop of local bedrock, which constitutes the seismic basement. This last horizon shows the same seismic characteristics as the basement observed in the reconnaissance surveys. The bedrock is characterised by two sharp drop-offs, which possibly document a tectonic event (Fig. 9b). The steep flanks of the island (Fig. 10b) correlate well with the local bedrock topography imaged by the 3D survey.

\section{Conclusions}

The SEAMAP-3D system was feasibly and effectively deployed at an archaeological site in Turkey. We were able to demonstrate that ultrahigh-resolution seismic data can be processed on-site in a standardized fashion. The inevitable reverberation caused by the use of a rigid seismic array can be effectively suppressed by deconvolution. Residual time shifts introduced by wave motion were satisfactorily corrected by a simple but effective 2D statics correction based on automatic seafloor digitisation and smoothing. The acquisition system and the documented processing approach provided stacked 3D seismic volumes with $25 \mathrm{~cm} \times 25 \mathrm{~cm}$ bin size.

Marine sediments investigated in the bay at Liman Tepe and surrounding Karantina Island are characterised by an overall very good seismic penetrability. The prominent seismic basement documents the paleo landscape. The Liman Tepe harbour structure is not seismically penetrable, but the topography of the structure is clearly defined in the seismic image. To the West of the Liman Tepe harbour structure the first 3D seismic survey revealed a small (2-3 m) local anomaly below seabed. Its archaeological relevance still has to be investigated.

No remains of the Roman villa foundation were detectable in the 3D seismic data set acquired at the Karantina Island site. This is either due to the fact, that the survey could not be performed close enough to the shoreline or that no building remains exist. However, the 3D seismic data set acquired in only 2-3 m water depth is of excellent data quality, revealing further insight into the complex geological setting very close to the shore of the island. The shallow part of the sediment sequence, as revealed by coring close to the 3D site, records the rapid accumulation and progradation of the coastline following the construction of the Alexander causeway. The paleo landscape was imaged in three dimensions. Two sharp drop-offs in the seismic basement document tectonic activity in the area. The bedrock also constitutes the seismic basement in our survey. It is characterised by a phase reversal and shows a rough topography comparable to that of the bedrock to the West of the island. Since sediment cores do not penetrate to the bedrock, we have no direct indicator towards the nature of this phase reversal. One possible explanation is a cover or concentration of organic material on the bedrock, which due to decay and gas production leads to a decrease in seismic impedance. Individual sediment units as revealed by coring can not be traced clearly in the 3D seismic volume due to a lack in impedance contrast. They are however visible on individual seismic sections. The use of residual static corrections based on common offset spatial averaging concept might further improve usable bandwidth and lateral coherence, in order to better image such weakly reflecting interfaces also in three dimensions.

\section{Acknowledgements}

We thank the Federal Ministry of Education and Research, Germany (BMBF - New Technologies for Philosophical Sciences) for funding the project.

Also acknowledged are discussion and support from Prof. G. Bakir (Ege-University, Turkey) and Prof. H. Erkanal (Ankara-University, Turkey).

Thanks to Detlef Schulte-Kortnack for the intensive technical support with hard- and software development.

Thanks to the students of the institute for taking an active part in the field work.

We also would like to thank Seismic Micro Technology for providing a university license grant for the Kingdom Suite seismic interpretation package.

\section{References}

Aksu, A.E., Piper, D., Konuk, T., 1987. Late quaternary tectonic and sedimentary history of outer Izmir and Candarli bays, Western Turkey. Marine Geology 76, 89.

Artzy, M., 2001. Liman Tepe 2001. University of Haifa Leon Recanati Institute for Maritime Studies 28, 3-4 Dec.

Bozkurt, E., Sobilir, H., 2004. Tectonic evolution of the Gediz Graben: field evidence for an episodic, two-stage extension in Western Turkey. Geological Magazine 141, 63-79.

Brinkmann, G., 1970. Geology of Turkey. Elsevier Scientific publishing Company, New York.

Bull, J., Gutowski, M., Dix, J., Henstock, T., Hogarth, P., White, P., Leighton, P., 2005. Design of a 3D chirp sub-bottom imaging system. Marine Geophysical Researches 26, 157-169.

Burns, G., Daoud, R., Vaigl, J., 1994. LAM: an open cluster environment for MPI. Proceedings of Supercomputing Symposium 379-386.

Ersoy, Y., 2004a. Klazomenai, Teos and Abdera: metropoleis and colony. In: Moustaka, A., Skarlatidou, E., Tzannes, A.-C., Ersoy, Y. (Eds.), Proceedings of the International Symposium held at the Archaeological Museum of Abdera (Abdera, 20-21 October 2001), pp. 77-95. 
Ersoy, Y., 2004b. Klazomenai: 900-500 BC. history and settlement evidence. In: Moustaka, A., Skarlatidou, E., Tzannes, A.-C., Ersoy, Y. (Eds.), Proceedings of the International Symposium held at the Archaeological Museum of Abdera (Abdera, 20-21 October 2001), pp. 43-76.

Goodman, B.N., Reinhardt, E., Dey, H., Boyce, J., Schwarcz, H., Sahoglu, V., Erkanal, H., Artzy, M., 2007. Evidence for Holocene marine transgression and shoreline progradation due to barrier development in Iskele, Bay of Izmir, Turkey. Journal of Coastal Research.

Gutowski, M., 2005. 3D high-resolution sub-bottom profiling - 3D chirp. Hydro International 2-4.

Henriet, J., Verschuren, M., Versteeg, W., 1992. Very high resolution 3D seismic reflection imaging of small-scale structural deformation. First Break 10 (3), 81-88.

Hürmüzlü, B., 2004. Burial grounds at Klazomenai: geometric through Hellenistic periods. In: Moustaka, A., Skarlatidou, E., Tzannes, A.-C., Ersoy, Y. (Eds.), Proceedings of the International Symposium held at the Archaeological Museum of Abdera (Abdera, 20-21 October 2001).

Krezoski, G., Boyce, J., Reinhardt, E., Goodman, B.N., Erkanal, H., Sahoglu, V., 2007. Coastal sediment record of the construction of Alexander the Great's causeway, Clazomenae, Turkey. Geological Society of America, Annual Conference, Denver, USA, vol. 39.

Marsset, B., Missiaen, T., De Roeck, Y., Noble, M., Versteeg, W., Henriet, J., 1998. Very high resolution 3D marine seismic data processing for geotechnical applications. Geophysical Prospecting 46 (2), 105-120.

Missiaen, T., Murphy, S., Loncke, L., Henriet, J., 2002. Very high-resolution seismic mapping of shallow gas in the Belgian coastal zone. Continental Shelf Research 22 (16), 2291-2301.
Müller, C., 2005. The marine VHR 2.5D seismic brute stack cube as a feasible tool for low budget investigation and research. Marine Geophysical Researches 26, 197-206.

Müller, C., Milkereit, B., Bohlen, T., Theilen, F., 2002. Towards high-resolution 3D marine seismic surveying using Boomer sources. Geophysical Prospecting 50, 517-526.

Pulliam, J., Austin, J., Luhurbudi, E., Saustrup, S., P.L., S., 1996. An ultrahigh resolution 3D survey of the shallow subsurface on the continental shelf of new Jersey. The Leading Edge 15 (7), 839-845.

Sahoglu, V., 2005. The Anatolian trade network and the Izmir region during the early bronze age. Oxford Journal of Archaeology 24, 349-352.

Scheidhauer, M., Marillier, F., Dupuy, D., 2005. Development of a system for 3D highresolution seismic reflection profiling on lakes. Marine Geophysical Researches 26 183-195.

Squyres, J.M., Lumsdaine, A., 2003. A component architecture for LAM/MPI. Proceedings, 10th European PVM/MPI Users' Group Meeting. . Lecture Notes in Computer Science, vol. No. 2840. Springer-Verlag, Venice, Italy, pp. 379-387. September / October.

Stockwell Jr., J.W., 1999. The CWP/SU: seismic unix package. Computers and Geosciences 25, 415-419.

Vardy, M.E., Dix, J.K., Henstock, T.J., Bull, J.M., Gutowski, M., 2008. Decimeter-resolution 3D seismic volume in shallow water: a case study in small-object detection. Geophysics 73 (No. 2).

Wardell, N., Diviacco, P., Sinceri, R., 2002. Pre-processing techniques for marine very high resolution 3D, (VHR3D) seismic data. First Break 20, 457-466. 